INDEPENDENT JOURNAL OF MANAGEMENT \& PRODUCTION (IJM\&P)

http://www.ijmp.jor.br

v. 12, n. 5, July-August 2021

ISSN: 2236-269X

DOI: 10.14807/ijmp.v12i5.1417

\title{
HEALTH AND SAFETY (HS) RISKS NORMALIZATION IN THE CONSTRUCTION INDUSTRY: THE SMEs PERSPECTIVE
}

\author{
Adesoji Anthony Adegboyega \\ Waziri Umaru Federal Polytechnic Birnin Kebbi, Nigeria \\ E-mail: adegboyegaadesoji@gmail.com
}

Chidiebere Emmanuel Eze Federal University of Technology Owerri, Nigeria E-mail: emmanueleze001@gmail.com

Onyinye Sofolahan Lagos State Polytechnic, Nigeria E-mail: onyxnwoko@gmail.com

Submission: 8/13/2020

Revision: 8/17/2020

Accept: 8/26/2020

\section{ABSTRACT}

The construction industry is hazardous and experiences poor health and safety performance records; as a result of the abuse and negligence of health and safety policies. Emphasis is now on health and safety management as health and safety risks are now normalised in the construction industry by the actions of construction SMEs. The study assessed the factors promoting health and safety risks normalisation in the construction industry of Nigeria. The study sampled construction professionals and tradespeople, using a well-structured questionnaire and snowball sampling techniques. With a response rate of $72.61 \%$ and a Cronbach's alpha value of 0.916; percentage, frequency, Mann-Whitney U Test and factor analysis were used to analyse the gathered data. It was found that there is a low level of occupational health and safety policies application and performance in the construction industry. The poor health and safety performance is prompted by HS risks normalisation promoted by factors such as misconception of and unwillingness to invest in HS, informal and unstructured HS policies, medical issues and excessive workload, Planning and client unwillingness, management commitment issues, and unorganised HS culture. Also, there was no statistically significant difference in the perceptions of the professionals and the tradespeople regarding $89.29 \%$ of the assessed 
DOI: 10.14807/ijmp.v12i5.1417

variables. Commitment from the management and leadership of the SMEs and making of health and safety culture an integral part of the functioning of the organisations was thus recommended.

Keywords: Health and safety risks; deviance normalisation; construction project; construction industry; construction SMEs; Nigeria

\section{INTRODUCTION}

The construction industry drives and influences economic growth and infrastructural development of nations. Eze et al. (2020) described the industry as the economic prime mover and the bedrock of survival of economies. Despite the benefits of the industry in the acceleration of growth and development, it is the most hazardous sector owing to its longstanding records of accidents and deaths (Abas et al., 2020; Sunindijo, 2015).

Globally, health and safety issues in the construction industry is a complex one as a result of the number of accidents and injuries involved (Aghimien et al., 2019; Othman et al., 2017; Chiocha et al., 2011). The industry is underdeveloped in developing countries and these have led to underperformance and substandard and total disregards of safety rules and measures which have subsequently resulted in accidents and other health problems (Aghimien et al., 2018; Laryea \& Mensah, 2010). Shabangu (2017) and Orji et al. (2016) submitted that it is now a commonplace among construction organisations to overlook health and safety management practices.

The construction industries of both developing and developed countries are dominated by the small and medium enterprise (SMEs), and their activities impacts on the socio-economic growth of the countries (Eze et al., 2020; Unnikrishnan et al., 2015; Arewa \& Farrell, 2012; Eashw, 2003). Construction small and medium enterprises (SMEs) has been blamed for the poor safety record of the construction industry.

EU-Osha (2014) for instance, reported that in Europe, 82\% of work-related injuries were caused by small organisations. The poor safety performance of the construction SMEs in relation to their large counterparts which have more robust safety management practices and performance (Sunindijo, 2015; Arocena \& Núñez, 2010; Kheni et al., 2010); can be attributed to deviance normalisation (risks normalisation) (Bell \& Healey, 2006).

Risks normalisation is the underlying reason why employees and management play deaf and blind to several warning signs before the occurrence of a disaster or accident. The poor 
INDEPENDENT JOURNAL OF MANAGEMENT \& PRODUCTION (IJM\&P)

http://www.ijmp.jor.br

v. 12, n. 5, July-August 2021

ISSN: 2236-269X

DOI: 10.14807/ijmp.v12i5.1417

safety performance of the small organisations have also been attributed to poor budgetary allocation to health and safety, financial insecurity, the use of part-time safety personnel, and informal safety arrangements (Stiles et al., 2012; Lin \& Mills, 2001).

Randy (2017) observed that the culture of placing more emphasis on productivity over safety, and indiscipline and lack of adherence to safety practices are key contributors to the normalisation of risks (Randy, 2017). The consequence of HS risks normalisation is accidents or disaster which could lead to loss of lives, incapacitation of employees, disruption of work, temporary suspension of work, rework and waste, loss of jobs, schedule extension, cost overrun, and disputes, among others. Furthermore, HS risks normalisation is not unconnected to the conditions under which construction projects are executed.

According to Szóstak (2019), construction projects are executed under a diverse and unpredictable condition in the construction industry. Throughout the entire year, construction activities are going on under a fluctuating atmospheric condition (Szóstak, 2019), which cannot accurately be predicted. This includes even the works carried out at evening and night times, especially when completion time is of the essence.

Continuous effective and efficient supervision and monitoring of the conditions under which tasks are carried out is a key to the effective management of HS risks normalisation. This could be the reason why Gunduz and Laitinen (2018) advocated for supplementing risk assessment with continuous monitory of the conditions under which work items are discharged. It was further maintained that monitoring would unearth the underlying causes like unsafe acts, mechanical hazards, order, tidiness, and ergonomics.

The variety of activities, operational modes and conditions under which the different professionals and tradespeople involved in construction projects carry out their tasks; increases the occurrence and magnitude of HS risks normalisation on construction projects.

In Nigeria, like other developing countries, the construction industry is also dominated by small and medium enterprises (SMEs). These organisations are characterised and influenced by a lot of internal and external forces. Dominant among these are; lack of proper documentation, instability in government and legislation, poor control of the resource, financial problems, inefficient business management and control, unsuitable scientific knowledge application, poor contractual risks management and response strategies, absence of practical scientific skills, insufficient skilled professionals, the existence of statutory requirements hampering growth, debilitated contract, inefficient materials management, lesser resources and 
DOI: 10.14807/ijmp.v12i5.1417

sole-leadership and - management system (Eze et al., 2020; Aghimien et al., 2019; Thwala \& Mvubu, 2009). These, however, make the SMEs suffer a consciously higher health and safety risks deviance practices than their large foreign and multi-national construction organisations counterparts.

While most research efforts on health and safety in the construction industry have been concentrated on large foreign and multi-national construction organisations (Ozmec et al., 2014), little has been done on SMEs (Legg et al., 2015), especially in the geographical area of the present study. Risks normalisation impedes effective health and safety management practices. Health and safety risks normalisation is inherent in the characteristic of the activities of the SMEs, and are promoted by certain barriers to effective health and safety management practices.

In order to improve health and safety performance of the construction SMEs in developing countries and beyond, this study assessed the factors promoting health and safety (HS) risks normalisation in the construction industry, using Nigeria as a case study. Possible measures for overcoming HS risks normalisation in the industry were recommended based on the findings. It is the understanding of this study that by knowing the major causes of health and safety risks normalisation and proffering solution to eliminate them would lead to an improvement in health and safety performance of the industry as a whole.

Furthermore, construction projects and SMEs performance will improve. Health and safety issue has been identified as one of the components of the social dimension of sustainable construction project delivery (Aghimien et al., 2019). Therefore, the outcome of this study will also find use in achieving the social dimension of sustainability; this will complement the economic and environmental dimensions of sustainable construction.

\section{REVIEW OF LITERATURE}

\subsection{Construction SMEs and Health and Safety Practices}

There is no universally acceptable definition of small and medium enterprises (SMEs). Definitions in extant literature have been centred on the number of employees and/or turnover. Those companies with not greater than 50 employees, not more than $£ 6.5$ million as turnover and a £3.26 million balance sheet total, is known as a small company. A company employing not more than 250 people, having turnover and a balance sheet total of not greater than $£ 25.9$ million and $£ 12.9$ million respectively is called a medium-sized company (Arewa \& Farrell, 2012; Berr, 2008). 
INDEPENDENT JOURNAL OF MANAGEMENT \& PRODUCTION (IJM\&P)

http://www.ijmp.jor.br

v. 12, n. 5, July-August 2021

ISSN: 2236-269X

DOI: 10.14807/ijmp.v12i5.1417

Small scale businesses employ not more than 50 full-time workers and total asset in (capital, plant and equipment and working capital) of not more than $\$ 250,000$ (Gulani \& Usman, 2012). The European Commission (2015) defined the SMEs as organisations with annual turnover and annual balance sheet total not greater than $€ 50$ million and $€ 43$ million respectively, and a population of employees of not greater than 250 people. The working definition of SMEs adopted in this study is presented in Table 1 and adopted from SMEDAN/NBS MSME Survey (2013) and the National Bureau of Statistics (2019). A Company with employees’ numerical strength of not less than 10 people and not more than 200 people, and with Assets (excluding land and buildings) of greater than 5million and not more than 500milion.

Table 1: Classification of CSMEs/MSMEs in Nigeria

\begin{tabular}{|c|c|c|c|}
\hline S/N & Size category & Employment & $\begin{array}{c}\text { Assets (A Million) (excluding } \\
\text { land and buildings) }\end{array}$ \\
\hline 1 & Micro enterprises & less than 10 & Less than 5 \\
\hline 2 & Small enterprises & 10 to 49 & 5 to less than 50 \\
\hline 3 & Medium enterprises & 50 to 199 & 50 to less than 500 \\
\hline
\end{tabular}

Sources: National Bureau of Statistics (2019); SMEDAN/NBS MSME Survey (2013)

Globally, construction SMEs constitutes a greater proportion of the construction industry of nations. This is both in developing and developed construction industries of the world. In Malaysia, Manu et al. (2018) reported that a substantial percentage of micro-business construction organizations are SMEs. CIDB (2018) report shows that $90 \%$ of construction firms are SMEs. In the EU, 99\% of businesses are SMEs, and in the UK, 99.9\% of the businesses involved with construction contracting are SMEs (Lu, 2018; European Commission, 2015). In Nigeria on which this study is based, $95 \%$ of the construction organisations in the industry are small and medium enterprises; and these SMEs are indigenous firms (Kolo, 2015).

SMEs drive innovation, economic growth, create employment and social integration both in the developed and developing economies of the world. Thus, are better described as 'development and economic drivers'. In Mexico, construction SMEs accounts for about 17.7\% GDP, 19\% in South Africa, 8\% in Ghana and 5\% in Nigerian (Usman et al., 2014). In spite of the benefits of the SMEs in national growth and development, they suffer from a lot of health and safety performance problems.

This was confirmed by Masi et al. (2014), who state that the SMEs experience worse conditions of occupational health and safety when compared to large firms; and these conditions are caused by the limited physical, economic and organisational resources. It was further maintained by Ying et al. (2015) that SMEs frequently overlook health and safety 
INDEPENDENT JOURNAL OF MANAGEMENT \& PRODUCTION (IJM\&P)

http://www.ijmp.jor.br

v. 12, n. 5, July-August 2021

ISSN: 2236-269X

DOI: 10.14807/ijmp.v12i5.1417

practices. In addition, small organisations in the EU contribute $67 \%$ to employment across all sectors but account for $82 \%$ health and safety fatalities (EU-OSHA, 2014). Health and Safety investment is considered a liability by most SMEs, and employees perceive it as an impediment to workflow efficiency (Zahoor et al., 2015; Mohamed et al., 2009).

Loosemore and Andonakis (2007) submit that the constant changes in the management and leadership of most SMEs in the contractual relationship have been blamed for the poor and inconsistent health and safety performance. Although, most projects where the SMEs play key roles are usually small and medium sized. This is supported by Belayutham and Ibrahim (2019) submission that construction SMEs occupies the general contractors' position on small and medium-sized projects, and in large projects where the large firms are the main contractors, they are sub-contractors.

According to Belayutham and Ibrahim (2019), SMEs uses occupational health and safety methods that are less formal. Sunindijo (2015) submit that in the large and more organisation construction firms who are constantly being engaged in large projects requiring a wide-ranging and detailed health and safety approaches; health and safety performance is better unlike what is obtainable in SMEs.

Construction projects being undertaken by SMEs have been reported to be prone and dominated by poor health and safety risks. This situation is attributed to the features and nature of the SMEs which can make health and safety risks normalisation to worsen. One of these features is poor financial strength. Financial issues have been attributed to be the major problems of the SMEs in implementing comprehensive health and safety management practices (Belayutham \& Ibrahim. 2019; Jaroenroy \& Chompunth, 2019; Surienty, 2012).

Financial constraints impact on the abilities of the SMEs to do proper planning and commitment to safety management programmes. Cash flow and payment issues from the main contractor or principals are another issues that hampers efficient health and safety practices of the SMEs (Lingard, 2013). Also, according to Hasle et al (2012), there is no clear cut difference between management and operations of the SMEs. Thus, this makes it difficult to separate health and safety management functions from the other operations of the company. Legg et al (2015) submit that the problems of SMEs are their heterogeneous nature, non-centralised representation, geographical spread (dispersion), organisational issues, limited market spread, insufficient access to external supports sources, and high level of resources limitations. 
DOI: 10.14807/ijmp.v12i5.1417

There is also a lack of proper in-house occupational health and safety policy and system documentation, poor knowledge of health and safety risks evaluation, poor knowledge of health and safety acts, regulations and code of practices.

Construction SMEs are known to use part-time hired skilled and unskilled labour forces; because they are more engaged as trades’ sub-contractors on most projects (Loosemore \& Andonakis, 2007). Kolo (2015) confirmed that a larger proportion of construction workers are temporary staff. Thus, there is the absence of a sense of job security in temporary employment, and these have also been blamed for lack of commitment to safety warnings.

Most of the unskilled workers are less educated and have issues reading, understanding and interpreting occupational health and safety (OHS) management manuals. According to Gao et al. (2017), this set of workers find it difficult to read and learn OHS manuals because of language and intellectual incompetence which undermine good safety practices. Also, labour nomadism and the temporary nature of employment practices of the SMEs make it difficult to retain workers that are knowledgeable about the company's health and safety policies. Casualization of workers also contributes to HS risks normalisation.

Contracting and sub-contracting organisations take advantage of casualization and temporary employment loopholes not to treat workers well. This according to Belayutham and Ibrahim (2019), makes it impracticable to keep and maintain workers over a long time. Also, the lack of unionism worsens the effort to manage safety among the SMEs (Loosemore \& Andonakis, 2007; Sunindijo, 2015). Stiles et al. (2012) submit that Small organisations are not financially secured, engage temporary safety personnel, insufficient budgetary allocation for safety implementation, and safety measures are not formalised. Hence, the normalisation of health and safety deviances.

\subsection{Factors Promoting Health and Safety (HS) Risks Normalisation in construction}

Deviance normalisation occurs when entities in an organisation continue and becomes used to certain deviant behaviours, which is no longer consider as deviant, even though, that behaviour is inconsistent with laid down rules for basic safety (Randy, 2017). A conscious decision of repeating as normal a risk that has not been injurious in the short term; thus, leading to accepting as standard the deviant conduct is known as risk normalisation (Jennings, 2016).

Deviance normalisation is also known as risk normalisation. In order to meet the task deadline, employees take shortcuts and these are sometimes tolerated or ignored by their line manager (supervisors). This attitude continues uncorrected and without caution, until it 
INDEPENDENT JOURNAL OF MANAGEMENT \& PRODUCTION (IJM\&P)

http://www.ijmp.jor.br

v. 12, n. 5, July-August 2021

ISSN: 2236-269X

DOI: 10.14807/ijmp.v12i5.1417

becomes a normal occurrence; even when it could lead to an unsafe act or even an accident. According to Randy (2017), normalisation of deviance is the reason why some organisations have better health and safety performance more than the other.

On a construction site, teams health and safety performance and even productivity differ as a result of deviance normalisation. Health and safety is every stakeholder's responsibility, thus, management, tradespeople and other project stakeholders are guilty of normalisation of deviance. This could be the reason why Jennings (2016) submitted that the acceptance of risks that were not acceptable originally could happen to a worker, a team or an organisation. The acceptance of deviance is a very slow (Jennings, 2016), gradual and conscious process.

Over time, organisations have cultivated the habit of tolerating well-known risks that had not caused harms previously (Jennings, 2016). The culture of placing more emphasis on productivity over safety, and indiscipline and lack of adherence to safety practices are key contributors to the normalisation of risks (Randy, 2017). Deviance normalisation hinders the effective practices and implementation of occupational health and safety in construction organisations.

HS risks normalisation is common among inexperienced employees as implied by (Szóstak, 2019). Szóstak (2019) found that employees with fewer years of work experience, often fall victim of accidents on-site as a result of; inadequate of occupational health and safety (OHS) training, working without medical fitness examinations, working with medical contraindications, ignorance of the principles and provision of OHS, inadequate concentration on activities being performed, inadequate experience, poor professional preparation as regards activity performance, ignorance of task execution with a work permit.

It was also submitted that employees of less than 30 years (20 to 29year) of age, are most prone to safety issues. Occupational health and safety risk normalisation are promoted by factors such as lack of training, prioritization of production over safety, inadequate manpower, employees attitude, planning issues, employees demands, not seeing benefits in prevention, defensiveness of employees, low literacy, language barriers, lack of management commitment to OHS, insufficient resources, organisational health and safety culture, lack of technical support (Masi et al., 2014; Whysall et al., 2006; Barbeau et al., 2004; Champoux; Brun, 2003).

In Australia, Ying et al (2015) identified cost, time and lack of awareness as the major groups of factors hindering the performance of small construction companies in health and safety practices. The basic factors according to Ying et al. (2015) include the absence of 
INDEPENDENT JOURNAL OF MANAGEMENT \& PRODUCTION (IJM\&P)

http://www.ijmp.jor.br

v. 12, n. 5, July-August 2021

ISSN: 2236-269X

DOI: 10.14807/ijmp.v12i5.1417

financial benefit in OHS investment, limited expertise, poor bargaining power, tight project deadline, long training and education time, underestimation of safety risks, fragmented nature of construction industry, and inconsistency of health and safety legislation.

Belayutham and Ibrahim (2019) investigated the barriers and strategies for better safety practices of Malaysian construction SMEs and found that the key barriers to good safety practices are the cost of implementation, insufficient safety culture, and client lack of commitment to safety issues.

Sunindijo (2015) grouped the factors that support HS risks normalisation into client demands, negative perception towards safety, Lack of safety knowledge and safety training and Poor safety culture. It was submitted that client interest is in getting an organisation that will deliver the project at the lowest cost possible, without due consideration to safety (Wadick, 2010). Thus, SMEs are under economic and competitive pressure to survive in the industry. The survival instinct makes most SMEs into placing less emphasis on safety but prioritises keeping a good relationship with their clients (Ozmec et al., 2014).

The high health and safety implementation cost and the extra resource involved (Floyde et al., 2013), have influenced the safety culture of most SMEs. Sunindijo (2015) the leadership and management of SMEs do not perceive safety as a priority, as such is not committed to its implementation. The responsibility for the control of safety risks in placed in the hands of the tradespeople who are majorly not full-time staff; they are usually blamed for any accidents or injury (Lingard \& Blismas, 2013). Ozmec et al. (2014) aver that the poor employees' attitudes to health and safety exacerbate because of the absence of commitment from the management of small organisations.

Another reason HS risks normalisation subsists in the construction industry is the negative perception by the owners of SMEs. Small construction companies' owners consider safety regulations and improvement as financial stress that is excessive and unattainable (Hasle and Limborg, 2006), this, however, hinders effective health and safety practices (Zhao et al., 2013).

Even with full knowledge of the harmful consequences of poor safety performance on the finances of the organisation, they still do not see reasons to eliminate OHSR normalisation (Okoye; Okolie, 2014). Jørgensen et al. (2011) posit that the sole-owners the SMEs do not have basic health and safety knowledge and as such do not appreciate the benefits of safety. 
INDEPENDENT JOURNAL OF MANAGEMENT \& PRODUCTION (IJM\&P)

http://www.ijmp.jor.br

v. 12, n. 5, July-August 2021

ISSN: 2236-269X

DOI: 10.14807/ijmp.v12i5.1417

It was further submitted by Hasle et al. (2010) and Wadick (2010) that safety training is considered insufficient to obtain the needed safety knowledge that will develop the right attitudes to safety practices. Most trade works are simple and repetitive; thus, the risks involved are often underrated and are perceived to be part of the work (Champoux \& Brun, 2003).

The factors supporting the HS risks normalisation are the abuse of safety equipment and items, deliberate ignorance in the use of personal protective equipment, inadequate working space, and deviation from normal safety rules (Arunkumar \& Gunasekaran, 2018).

Shafii et al. (2019) found that the major problems affecting OHS performance of construction sites are attitude of workers, poor budgetary allocation, absence of safety policies enforcement, week management support, and awareness and understanding issues regarding occupational safety. In order of relative importance, Kadiri et al. (2014) found that the key factors that promote HS risks normalisation include lack of attention from management leaders, recklessness, poor safety conscientiousness of managers, use of non-certified skilled tradespeople, lack of training, poor equipment maintenance weak enforcement of safety regulations, unstable organisational commitment to safety.

According to Williams et al. (2018), the top causes of HS risks normalisation are; Absence of personal protective equipment, faulty and unsafe equipment, Absence of training, low consciousness of employees to safety, Unsecured process of handling materials and equipment, inexperienced project manager and /or tradespeople, Tiredness excess workload by workers, poor and unsafe workplace conditions, lack of willingness to invest on safety by management, lack of compliance to safety regulations and Insufficient housekeeping program.

Major contributors to health and safety deviance normalisation are profit insatiability of contractors, the misconception that investment in the impact project budget, ignorance of workers, poor site and organisation management, need to meet the project deadline, lack of safety training, and inadequate safety experts (Zahoor et al., 2015; Rizwan, 2012).

\section{RESEARCH METHODOLOGY}

This study assessed the factors promoting health and safety risks normalisation by construction SMEs in the construction industry of Nigeria. The study was carried out in Abuja, Nigeria and data were drawn from construction professionals and tradespeople. Abuja is the seat of power of Nigeria and the rate of infrastructural and building provision by both the government and private sector is unprecedented. This attracts large and SMEs constructionbased organisations into citing the head office or annexe in Abuja. 
INDEPENDENT JOURNAL OF MANAGEMENT \& PRODUCTION (IJM\&P)

http://www.ijmp.jor.br

v. 12, n. 5, July-August 2021

ISSN: 2236-269X

DOI: 10.14807/ijmp.v12i5.1417

The choice of Construction SMEs is premised on the fact that they form bulk of the construction organisations in the construction industry, and they are greatly lacking behind on health and safety issues (Eze et al., 2020; Sunindijo, 2015). Constructions SMEs are engaged as sub-contractors in large projects, and in small and medium-sized projects, they are the main contractors (Belayutham \& Ibrahim, 2019). Thus, are involved in all construction contract types and sizes, and plays key roles in delivering construction projects of both private and public nature. Thus, assessing the major health and safety risks normalisation and proffering solution to eliminate them would lead to an improvement in health and safety performance of the industry as a whole.

The sampled population includes construction professionals (Architects, Engineers, buildings, quantity surveyor, and certified health and safety officers) and tradespeople (Carpenters, Masons (bricklayers \& Concreters), Steel benders \& fixers, painters, Tilers and services (mechanical \& electrical)). The professionals are the majority of the key built environment experts' employees of both the contracting and sub-contracting organisations (Eze et al., 2020). Tradespeople were considered because they are the category of workers that are physically and directly involved in executing the construction works and production of the finished building (Eze et al., 2017).

Also, the common trades in building construction are masonry, carpentry, iron bending and steel fixing, painting, tiling, electrical fittings and plumbing; these trades are associated with medium to high occupational health and safety risks (Okoye, 2018). In addition, labourers, artisans, supervisors and foremen are the class of workers most affected by the consequences of OHS risks normalisation regardless of the company size (Kadiri et al., 2014). Tradespeople considered were foremen, supervisors, headmen, onsite-trained safety men and other skilled workers who grew on the job and met the set criteria.

The report of a national survey carried out in 2017 on Micro, small and medium enterprises and published by National Bureau of statistics in 2019 showed that out of a total of 41,543,028 Micro, Small, and Medium Enterprises; 71,288 are a small enterprise and 1,793 are medium firms. $1 \%$ and $5 \%$ of the small and medium firms respectively are into construction businesses. The number of each involved in the construction business is 712.88 for small firms and 89.65 for medium firms.

About $4.11 \%$ of these SMEs are in Abuja when applied on the number of SMEs involved in the construction business, gives 30 and 4 small and medium firms respectively. 
DOI: 10.14807/ijmp.v12i5.1417

Based on the proposed number of the target respondents, a population of $230(150+80)$ was obtained (see Table 2). The sample size adopted was 230 (same as the sample population). This was used because the population is sizeable, manageable and not too large for a 'samples size determination formula to be applied.

Table 2: Population and Size of Samples

\begin{tabular}{llcc}
\hline & & \multicolumn{2}{c}{ Enterprise type } \\
\cline { 2 - 4 } & & Small & Medium \\
\hline \multirow{3}{*}{ construction businesses } & Number of each type & 71288.00 & 1793.00 \\
& per cent proportion & $0.1716 \%$ & $0.0043 \%$ \\
& \% Proportion in the country & $1.0 \%$ & $5.0 \%$ \\
construction SMEs in Abuja & Number involved in the construction business & 712.88 & 89.65 \\
& Approximate Proportion of SMEs & $4.11 \%$ & $4.11 \%$ \\
& Number of construction SMEs & 30.00 & 4.00 \\
& Proposed sample & 5 & 20 \\
& Total Number of proposed Sample & 150 & 80 \\
\hline
\end{tabular}

The study leveraged on the importance of questionnaire and snowball sampling techniques in administering and collection of data. A well-structured quantitative research questionnaire was used in the administration of the questionnaire using snowball sampling techniques on construction professionals and tradespeople.

The criteria that guided the sampling and selection of participants are; employees (professionals and tradespeople) with at least 5 years work experience, have taken part in at least 2 projects with the same or different employers, and currently engaged in an active site. This is to ensure that only quality and unbiased data are collected. The questionnaire is commonly used in construction management related researches; it can cover large audience at shorter time (Bagaya \& Song 2016; Tan, 2011).

This makes it an economic data collection instrument for Abuja with a lot of SMEs scattered all over the six area councils. Naderifar et al. (2017) described snowball sampling as a convenient sampling technique used for subjects with target features and that are hard to access. Snowball sampling method is based on referrals, it is less time consuming and economical; and response bias is very low since samples have homogenous characteristics (Heckathorn, 2011; Naderifar et al., 2017). Snowball sampling according to Atkinson and Flint (2001), significantly increase the sample size of the study.

Participants who met the set criteria were first identified and selected based on their inclination to partake in the investigation (Cresswell \& Plano, 2011). They also referred the researchers to potential participants who met the criteria for inclusion. The researchers and 
INDEPENDENT JOURNAL OF MANAGEMENT \& PRODUCTION (IJM\&P)

http://www.ijmp.jor.br

v. 12, n. 5, July-August 2021

ISSN: 2236-269X

DOI: 10.14807/ijmp.v12i5.1417

trained research assistants self-administered the questionnaires to the participants using the set criteria.

To avoid delay of work progress of the sampled tradespeople, part of their lunch period were solicited and used to administer the questionnaire to them. This was done to give ample time for clarification and focus by both the researchers and participants. However, busy and non-responding samples were repeatedly reminded in order to increase participation. The questionnaire used constitute of three parts; the first part gathered data on the basic information of the respondents; these data serve as a quality check to data collected on other parts.

The second part collected data on the level of application health and safety practices by construction SMEs, and the third part garnered data on the factors promoting health and safety (HS) risks normalisation on construction projects. The scale used in part 2 and 3 of the questionnaire were based on a 5-point Likert scale; with 1 being the lowest and 5 being the highest. The 28 assessed factor promoting health and safety risks normalisation on construction projects were selected from the detailed literature review.

After a ten weeks sampling period, 167 effective and properly filled questionnaires were collected. This represents a response rate of $72.61 \%$ and this was adjudged adequate for analysis. This response rate is greater than $30 \%$ known as the acceptable rate for statistical and dependable analysis (Ye et al., 2015). A Cronbach's alpha value of 0.916 was obtained for the 28 identified factors promoting HS risks normalisation.

Hair et al. (2010) suggested a Cronbach's alpha value of 0.70 and above for a good internal consistency. Based on this, the data collected were established to have a very high internal consistency and reliability, unbiased and of high quality. The normality assumption test was further carried out using the 'Shapiro-Wilk test'. Ghasem and Zahediasl (2012) recommended the use of the Shapiro-Wilk test for sample size fewer than 2000. A p-value of less than 0.05 was obtained for the variables assessed, based on this, the data failed normality assumption and, thus, are non-parametric.

Data analysis was done using percentage, frequency, Mann-Whitney U Test and factor analysis. Data collected on the basic information of the respondents and the level of application health and safety practices by construction SMEs were analysed using frequencies and percentages. The data collected on the factors promoting health and safety risks normalisation on construction projects were analysed using Mann-Whitney U-Test and exploratory factor analysis (EFA). 
The extraction method used is principal component analysis (PCA) and the rotation method used is varimax rotation. Exploratory factor analysis (EFA) was used to reduce the variables by grouping them into components and manageable proportion, based on the inherent relationship in the cluster. Furthermore, EFA is a common statistical analytical tool used among health- and safety-related management researches and other construction-related studies in the construction industry.

The Mann-Whitney U Test was used to determine the difference in the views of the two participants group since the data is non-parametric. Pallant (2005) submit that Mann-Whitney $\mathrm{U}$ test is suitable for comparing medians of two participants group; the scores of the groups are converted on the continuous variable in order to rank and define the significant difference existing between the groups.

This test assisted in the ascertainment of the variables in which the participants' perception differs and also the proportion of the variables with the same rating style. This is based on the understanding that there could be a difference in the rating style of the identified factors by both the professionals and the tradespeople. All analyses in this present study were presented using Tables and chats. Also, the statistical package for social science (IBM, 2011) was used to perform the analyses. The methodological procedures for the study is summarised in the six-step flow in Figure 1 below.

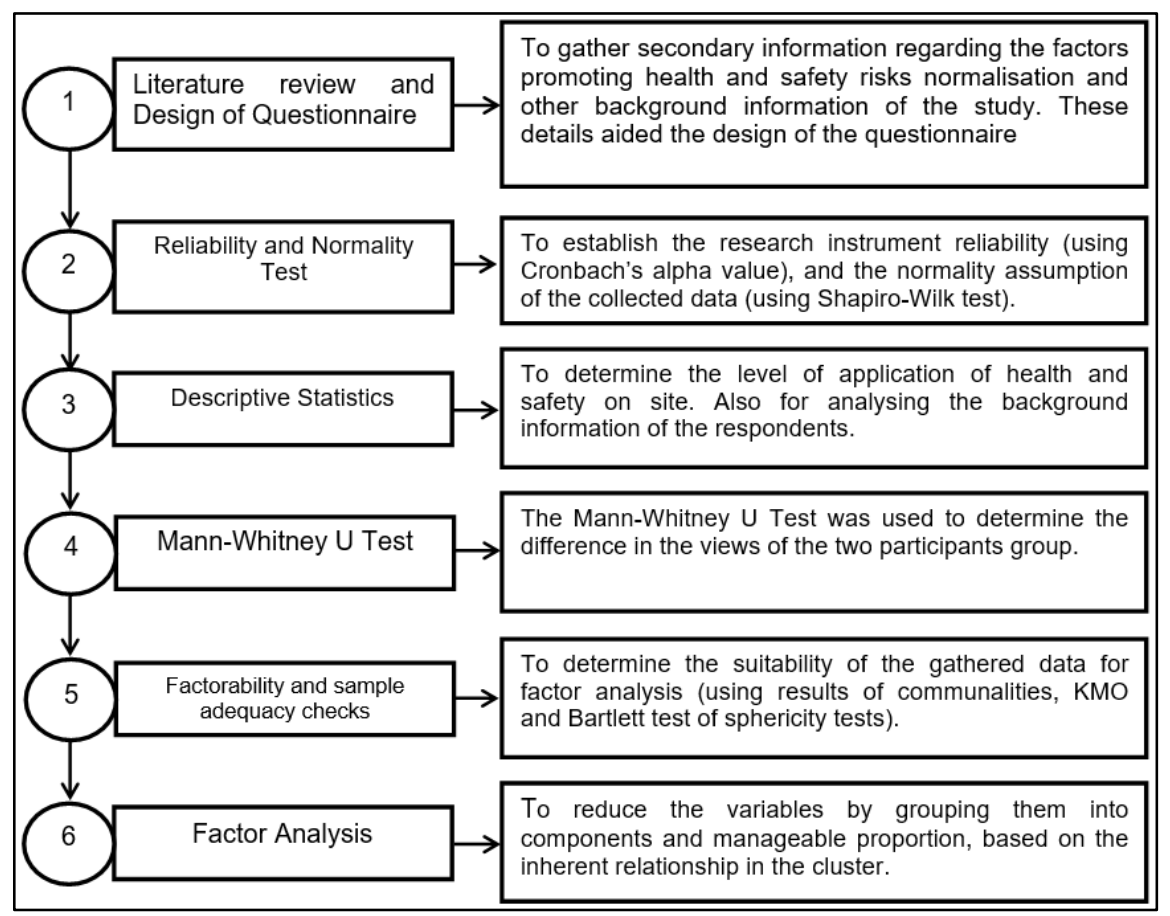

Figure 1: Flow of methodological procedures

\section{RESULTS AND DISCUSSION}


DOI: 10.14807/ijmp.v12i5.1417

\subsection{Basic information about the respondents' group}

The analysis of the basic information of the respondents in Table 3 shows that $54.49 \%$ of them work with small construction organisations and $45.51 \%$ work with the medium-sized organisation. This shows a fair representation of the participants from the two organisational types. In terms of employees' category, 34.73\% are construction professionals and $65.27 \%$ are tradespeople (craftsmen/artisans).

This is a typical reflection of the human resource composition of construction project sites. With regards to their working experience, $37.13 \%$ of the respondents have spent about 11-15years in the construction industry, followed by 33.53\% that have spent 5-10 years, then $16.77 \%$ have spent 16 -20years and $12.57 \%$ have spent 21years and above in the industry. The mode and median class being 11-15years, thus, showing that the respondents are experienced to give an insight into health and safety issues and deviance normalisation of their employers and in the construction industry generally.

Concerning the number of projects executed, 32.34\% have taken part in 6-9 projects, $30.54 \%$ have taken part in 2-5 projects, $23.95 \%$ have been involved in $10-13$ projects and $13.17 \%$ of them have executed more than 14 projects. This is a reflection of the number of years they have spent in the construction industry, and the quality of experienced gained in the industry.

Furthermore, the professional composition of the construction professionals' group shows that out of the 58 professional participants; 36.21\% are Engineers (Civil \& Services), 31.03\% are Architect, 18.97\% are Quantity Surveyors, and 13.79\% are Builders. Also, out of the 109 tradespeople that participated in the survey, 16(14.68\%) are Carpenters, 33(30.28\%) are masons, 21(19.27\%) are Painters, 11(10.09\%) are into services (electrical \& plumbing), 16 (14.68\%) are Tilers, and 12 (11.01\%) are Steel benders + fixers.

The length of years spent in the construction industry and the number of projects executed by the participants implies that the participants have the requisite knowledge on the subject of this study.

Table 3: Basic Information of Respondents

\begin{tabular}{llcc}
\hline Variables & Classification & Frequency & Per cent \\
\hline Organisational Type & Small organisations & 91 & 54.49 \\
& Medium organisations & 76 & 45.51 \\
Category of employees & TOTAL & $\mathbf{1 6 7}$ & $\mathbf{1 0 0}$ \\
& Construction professionals & 58 & 34.73 \\
& Tradespeople (craftsmen/artisans) & 109 & 65.27 \\
& TOTAL & $\mathbf{1 6 7}$ & $\mathbf{1 0 0}$
\end{tabular}


ISSN: 2236-269X

DOI: 10.14807/ijmp.v12i5.1417

Years of experience

Number of projects executed

Profession of construction professionals

Tradespeople (craftsmen/artisans) Skill areas

5-10years
11-15 years
16-20 years
21-above
TOTAL
2-5 projects
6-9 projects
10-13 projects
14 projects and above
TOTAL
Architect
Builders
Engineers (Civil \& Services)
Quantity Surveyors
TOTAL
Carpenter
mason
Painters
Services (electrical \& plumbing)
Tilers
Steel benders + fixers
TOTAL

TOTAL

\begin{tabular}{cc}
56 & 33.53 \\
62 & 37.13 \\
28 & 16.77 \\
21 & 12.57 \\
$\mathbf{1 6 7}$ & $\mathbf{1 0 0}$ \\
51 & 30.54 \\
54 & 32.34 \\
40 & 23.95 \\
22 & 13.17 \\
$\mathbf{1 6 7}$ & $\mathbf{1 0 0}$ \\
18 & 31.03 \\
8 & 13.79 \\
21 & 36.21 \\
11 & 18.97 \\
$\mathbf{5 8}$ & $\mathbf{1 0 0}$ \\
16 & 14.68 \\
33 & 30.28 \\
21 & 19.27 \\
11 & 10.09 \\
16 & 14.68 \\
12 & 11.01 \\
$\mathbf{1 0 9}$ & $\mathbf{1 0 0}$ \\
\hline
\end{tabular}

\subsection{Level of application health and safety practices by construction SMEs}

On the level of application of health and safety by the organisation on construction site (Fig. 2), 73(43.71\%) indicated that it is low, 44 (26.35\%) indicated that it is averagely applied, 29(17.37\%) indicated a very low level of application, 21(12.57\%) indicated high application level and only 9(5.39\%) indicated a very high level of application. This result implies that the occupational health and safety application and performance of the SMEs ranges from very low to average; as the total is $146(87.43 \%)$.

It also reflects the level of conscious and deliberate negligence and non-adherence to health and safety by SMEs. This negligence of health and safety by both management and other stakeholders lends credence to health and safety risks normalisation in the construction industry. These result support findings from extant literature regarding the poor application and performance of occupational health and safety of construction SMEs.

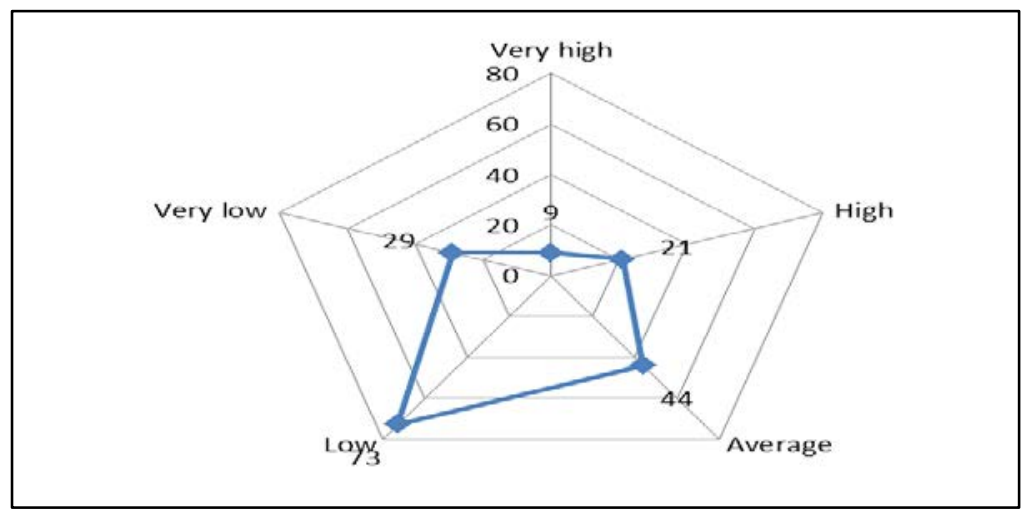


DOI: 10.14807/ijmp.v12i5.1417

Figure 2: Application of health and safety on Site

\subsection{Factors promoting health and safety (HS) risks Normalisation}

In order to determine the variables were the participants' perception differs and also the proportion of the variables with the same rating style, Mann-Whitney U-Test was conducted. The test revealed that the rating pattern of 25(89.29\%) of the variables is the same. This implies that there no statistically significant difference in the perception of the professionals and the tradespeople regarding these variables. This is premised on the p-value obtained for these variables are greater than 0.05 .

It further follows that the participants have a convergent view of the 25 variables. Similarly, the perception of the participants differs in 3(10.71\%) of the variables assessed. This is evident in the p-value obtained which is below 0.05. Thus, there is a significant statistical difference in the perception of these variables. These variables as shown in Table 4 are; Lack of use of personal protective equipment $(Z=-2.186)$, Allowing workers to control of safety risks $(Z=-4.290)$, and execution of work without a work permit $(Z=-3.546)$.

It means that the professionals and the difference tradespeople have divergent opinion on these 3 variables, and thus were rated differently. The difference in the rating could be that lack of use of personal protective equipment, allowing workers to control safety risks and execution of work without a work permit are already part of the workings of the sampled organisations' projects. That is to say that these health and safety risks have been normalisation and now an integral part of the workers and by extension their employer's operational methods.

Before carrying out the detailed factor analysis (FA), the factorability, sample adequacy and suitability of the gathered data were determined. This includes checking the adequacy of the sample size, number of variables, commonalities, Kaiser-Meyer-Olkin (KMO) measure of sampling adequacy, and Bartlett's test of sphericity. From the recommendations of Pallant (2007) and Tabachnick and Fidell (2007), the 167 sample size is adequate for factor analysis. Zhao (2008) submits that ones the communalities value is at least 0.60 , the sample size becomes meaningless in determining the factorability of variables.

The respective maximum and minimum communalities values obtained for the variables are 0.803 and 0.533 and the mean communalities value is 0.694 . Researchers are yet to come to a consensus regarding what should be the best number of variables that will be suitable for factor analysis; thus, making the 28 identified factors adequate for FA. The KMO 
DOI: 10.14807/ijmp.v12i5.1417

value for the 28 variables is 0.723 which is above the suggested cut-off score of 0.50 (Field 2000; Hair et al. 2010).

A chi-square value of 2369.131 and p-value of 0.0000 was obtained from the Bartlett test carried out. This supports the submission of Tabachnick and Fidell (2007) regarding the factorability of data. Bartlett's test of sphericity results shows that the existence of a relationship between the variables. Based on the foregoing, the data gathered were declared factorable, adequate and suitable for factor analysis. Therefore, factor analysis was subsequently performed.

Six factors were retained following the FA carried out using PCA with varimax rotation. These factors accounted for about $61.73 \%$ of the total cumulative variance, and their eigenvalues are higher than 1 . The $61.73 \%$ obtained for the extracted factors is higher than $50 \%$ proposed by Pallant (2007) and Stern (2010), and 60\% proposed by Hair et al. (2010) for adequate construct legitimacy. Spector (1992) posits that a strong component structure is present when the factor loading on each component is 0.50 or more. Based on these, the variables retained have their factor loading to be equal to or greater than 0.50 (see Table 4).

The name of components in FA is influenced by the variables under the components. This was confirmed by Abdi and Williams (2010). They posit that considerations should be given to the highest item within a component in naming the component. This study, however, considered the next 2 top items and the latent characteristics of other items and in addition to the highest item in naming the components.

Table 4. Factors Promoting of Health and safety risks normalisation

\begin{tabular}{|c|c|c|c|c|c|c|c|c|}
\hline & \multicolumn{6}{|c|}{ Component } & \multicolumn{2}{|c|}{$\begin{array}{c}\text { Mann-Whitney } \\
\text { U }\end{array}$} \\
\hline & 1 & 2 & 3 & 4 & 5 & 6 & $\mathbf{Z}$ & Sig. \\
\hline poor budgetary allocation & 0.770 & & & & & & -0.462 & 0.644 \\
\hline Failure to see the benefit in OHS investment & 0.720 & & & & & & -1.214 & 0.225 \\
\hline low literacy and language barriers & 0.692 & & & & & & -0.595 & 0.552 \\
\hline tight project delivery deadline & 0.673 & & & & & & -0.918 & 0.359 \\
\hline Inexperienced project manager and /or tradespeople & 0.668 & & & & & & -0.043 & 0.966 \\
\hline inadequate concentration on activities being performed & 0.528 & & & & & & -1.533 & 0.125 \\
\hline ignorance of the principles and provision of OHS & 0.552 & & & & & & -0.262 & 0.793 \\
\hline Poor enforcement of safety regulations & 0.500 & & & & & & -0.663 & 0.507 \\
\hline inconsistency of health and safety legislation & & 0.779 & & & & & -0.330 & 0.741 \\
\hline underestimation of safety risks & & 0.752 & & & & & -0.173 & 0.862 \\
\hline employees attitude and defensiveness & & 0.555 & & & & & -0.190 & 0.850 \\
\hline Abuse of and lack of maintenance of tools and equipment & & 0.531 & & & & & -0.396 & 0.692 \\
\hline working without medical fitness examinations & & & 0.682 & & & & -0.503 & 0.615 \\
\hline Excess workload by workers & & & 0.624 & & & & -1.357 & 0.175 \\
\hline inadequate manpower & & & 0.621 & & & & -0.470 & 0.639 \\
\hline Lack of use of personal protective equipment & & & 0.546 & & & & -2.186 & $0.029 * *$ \\
\hline Tasks planning issues & & & & 0.709 & & & -0.709 & 0.478 \\
\hline Client lack of commitment to safety issues & & & & 0.601 & & & -0.766 & 0.444 \\
\hline The high health and safety implementation cost & & & & 0.603 & & & -1.710 & 0.087 \\
\hline Allowing workers to control of safety risks & & & & 0.594 & & & -4.299 & $0.000^{* *}$ \\
\hline
\end{tabular}


ISSN: 2236-269X

DOI: 10.14807/ijmp.v12i5.1417

\begin{tabular}{|c|c|c|c|c|c|c|c|c|}
\hline execution of work without work permit & & & & 0.538 & & & -3.546 & $0.000^{* *}$ \\
\hline management commitment and conscientiousness to HS & & & & & 0.731 & & -0.589 & 0.556 \\
\hline placing more emphasis on productivity over safety & & & & & 0.625 & & -1.645 & 0.097 \\
\hline Use of temporary workers and safety personnel & & & & & 0.614 & & -1.552 & 0.121 \\
\hline inadequate occupational health and safety training & & & & & 0.543 & & -0.343 & 0.732 \\
\hline poor organisational health and safety culture & & & & & & 0.761 & -0.110 & 0.912 \\
\hline Poor housekeeping and unsafe workplace conditions & & & & & & 0.753 & -1.059 & 0.290 \\
\hline indiscipline and lack of adherence to safety practices & & & & & & 0.563 & -0.290 & 0.772 \\
\hline Eigenvalues & 6.83 & 3.30 & 2.34 & 1.77 & 1.64 & 1.39 & & \\
\hline$\%$ of Variance & 24.41 & 11.80 & 8.36 & 6.32 & 5.86 & 4.98 & & \\
\hline Cumulative $\%$ of the variance & 24.41 & 36.21 & 44.58 & 50.89 & 56.75 & 61.73 & & \\
\hline number of extracted variables & 8 & 4 & 4 & 5 & 4 & 3 & & \\
\hline
\end{tabular}

\subsection{Discussion of Extracted factors}

From the result in Table 4, eight (8) items were strongly loaded in the first component and accounts for about $24.41 \%$ of the total variance of the retained variables. These items are; poor budgetary allocation, failure to see a benefit in OHS investment, low literacy and language barriers, tight project delivery deadline, Inexperienced project manager and /or tradespeople, inadequate concentration on activities being performed, ignorance of the principles and provision of OHS, and poor enforcement of safety regulations.

A cursory examination of these variables led to the naming of this component as 'misconception of and unwillingness to invest in HS'. The misconception of and unwillingness to invest in health and safety is one of the reasons why there have been continuous health and safety risks normalisation and the non-disappearance of accidents on construction sites. Zahoor et al. (2015) and Mohamed et al. (2009) posits investing in health and safety is perceived a liability by most construction SMEs, and this is even made worse by workers perception of safety as a barrier to their work speed.

Williams et al. (2018) reported that among the top causes of HS risks normalisation are; absence of training, low consciousness of employees to safety, inexperienced project manager and /or tradespeople, lack of willingness to invest on safety by management, and lack of compliance to safety regulations. Arunkumar and Gunasekaran (2018) also found ignorance and deviation from normal safety rules as being among the causes of accidents. Hasle and Limborg (2006) reported that small construction companies' owners consider safety regulations and improvement as financial stress that is excessive and unattainable. Zhao et al. (2013) affirmed that the misconception of managers of SMEs hinders an effective health and safety practices.

The second component was named 'informal and unstructured HS policies' following a careful examination of the latent characteristics of the items loading strongly under it. This 
INDEPENDENT JOURNAL OF MANAGEMENT \& PRODUCTION (IJM\&P)

http://www.ijmp.jor.br

v. 12, n. 5, July-August 2021

ISSN: 2236-269X

DOI: 10.14807/ijmp.v12i5.1417

component contains 4 items and accounts for $11.80 \%$ of the total variance explained. These items are; inconsistency of health and safety legislation, underestimation of safety risks, employees attitude and defensiveness, and abuse of and lack of maintenance of tools and equipment.

Health and safety risks normalisation is promoted in an environment where there is the inconsistency of health and safety legislation, underestimation of safety risks, attitude and defensiveness of the frontline workers, and the persistent abuse and absence of maintenance of tools and equipment by both workers and organisation. This corroborates the submissions of (Arunkumar \& Gunasekaran, 2018; Ying et al., 2015; Masi et al., 2014).

Among the factor hindering the performance of small construction companies in health and safety practices are an underestimation of safety risks and inconsistency of health and safety legislation (Ying et al., 2015). One of the factors supporting HS risks normalisation is the abuse of safety equipment and items, deliberate ignorance in the use of personal protective equipment. Employees' attitude and defensiveness of employees were identified as being among the causes of HS deviance normalisation and the non-reduction of accidents on site (Masi et al., 2014).

The third component is made up of four items and accounts for $8.36 \%$ of the total variance explained. The items loading under these components are working without medical fitness examinations, excess workload by workers, inadequate manpower, and lack of use of personal protective equipment. This component was named 'Medical issues and excessive workload' following the examination of the highest item loading and the characteristics of the other items.

Allowing workers to begin work without conducting fitness examination and waiting for the result prior to granting access to the workplace has been blamed for the continuous accident on site. Underlying illnesses could have been known and even treated or employee drop in order not to constitute safety risks on site. The competition among workers to get more money for the day's work and greed to continue remaining important has led to workers carrying more workload than their capacity.

This leads to accidents and death of a lot of workers in the construction sites as a result of tiredness and exhaution. Inadequate manpower of various capability and the non-use of PPE during work execution promotes HS risks normalisation. This finding supports the study of (Masi et al., 2014; Kadiri et al.2014; Whysall et al., 2006). 
INDEPENDENT JOURNAL OF MANAGEMENT \& PRODUCTION (IJM\&P)

http://www.ijmp.jor.br

v. 12, n. 5, July-August 2021

ISSN: 2236-269X

DOI: 10.14807/ijmp.v12i5.1417

The fourth component is named 'Planning and client unwillingness'. This component has five items accounting for about $6.32 \%$ of the total variance explained. These items are; tasks planning issues, client lack of commitment to safety issues, the high health and safety implementation cost, allowing workers to control of safety risks and execution of work without a work permit. HS deviance normalisation is promoted by poor or lack of planning of work by the SMEs. Planning of work or trades involves the consideration of the quality of worker to be used, safety of work execution and work content.

The engagement of SMEs on the grounds of sentiment and other factors that do not promote adequate health and safety by clients is among the causes of the persistence of safety issues in the construction industry. Client lack of commitment to safety is one of the reasons for the awards of a contract without consideration of safety in the selection criteria of contractors.

Belayutham and Ibrahim (2019) found that one of the key barriers to good safety practices by construction SMEs is client lack of commitment to safety issues. Client interest is in getting an organisation that will deliver the project at the lowest cost possible, without due consideration to safety (Wadick, 2010).

The cost of health and safety implementation is perceived to be high and unimportant for investment by construction SMEs. Construction SMEs carelessness is one of the reasons for leaving safety in the hands of the workers that are not even knowledgeable enough. Furthermore, the habit of granting access to the site for work execution without a permit by the management of SMEs is a factor promoting HS risks normalisation.

The fifth component has four items and accounts for $5.86 \%$ of the total variance explained, and was named 'Management commitment issues'. This name is premised on the analysis of the latent features of the items loaded under component 5. These items are management commitment and conscientiousness to health and safety, placing more emphasis on productivity over safety, use of temporary workers and safety personnel, and inadequate occupational health and safety (OHS) training.

Ozmec et al. (2014) submit that the absence of commitment from the management of small organisations exacerbates the poor HS employees' attitudes. Shafii et al. (2019) found that the major problems affecting occupational health and safety performance of construction sites are week management support and awareness and understanding issues regarding occupational safety. 
DOI: 10.14807/ijmp.v12i5.1417

The key factors that promote HS risks normalisation include lack of attention from management leaders, recklessness, poor safety conscientiousness of managers, and unstable organisational commitment to safety (Kadiri et al.2014). Management commitment is key to the HS performance of construction SMEs. Where there is lack of or weak management support for health and safety practices; there will be lack of organisation of safety training, use of unsafe tools and equipment, weak regulation and enforcement of safety policies and other negative vices that have made HS deviances a normal thing in the construction industry.

The sixth components account for $4.98 \%$ of the total variance explained and the $61.73 \%$ cumulative variance of the extracted factors. This component contains 3 items which are poor organisational health and safety culture, poor housekeeping and unsafe workplace conditions indiscipline and lack of adherence to safety practices.

A cursory examination of the characteristics of these items shows they are closely related to health and safety cultural practices of the organisations it is based on this that this component is named 'unorganised HS culture'. The taking of HS deviance as normal in the construction industry is a result of the poor health and safety management culture of the construction SMEs. This is a major cause of accidents and the continuous poor safety performance of the SMEs.

Belayutham and Ibrahim (2019) found that insufficient safety culture by construction SMEs is a critical barrier to their health and safety performance. The safety culture is influenced by the high cost of safety implementation and extra resources required for managing safety (Floyde et al., 2013). The lack of commitment and prioritisation and placing of safety control in the hands of casual and temporary workers of safety is a product of the inherent safety culture and environment of the SMEs (Sunindijo, 2015; Lingard \& Blismas, 2013).

Overall, based on the relative mean of the extracted factors' loading in percentage shown in fig. 3, all the extracted factors contribute to the poor health and safety performance of the SMEs. Thus, are the critical promoters of HS deviance normalisation in the construction industry of Nigeria and indeed other developing countries of the world. However, unorganised health and safety culture, Informal and unstructured HS policies, and Misconception of and unwillingness to invest in HS with 69.23\%, 65.43\% and 63.79\% respectively, influences and promotes health and safety risks normalisation the more. 
DOI: 10.14807/ijmp.v12i5.1417

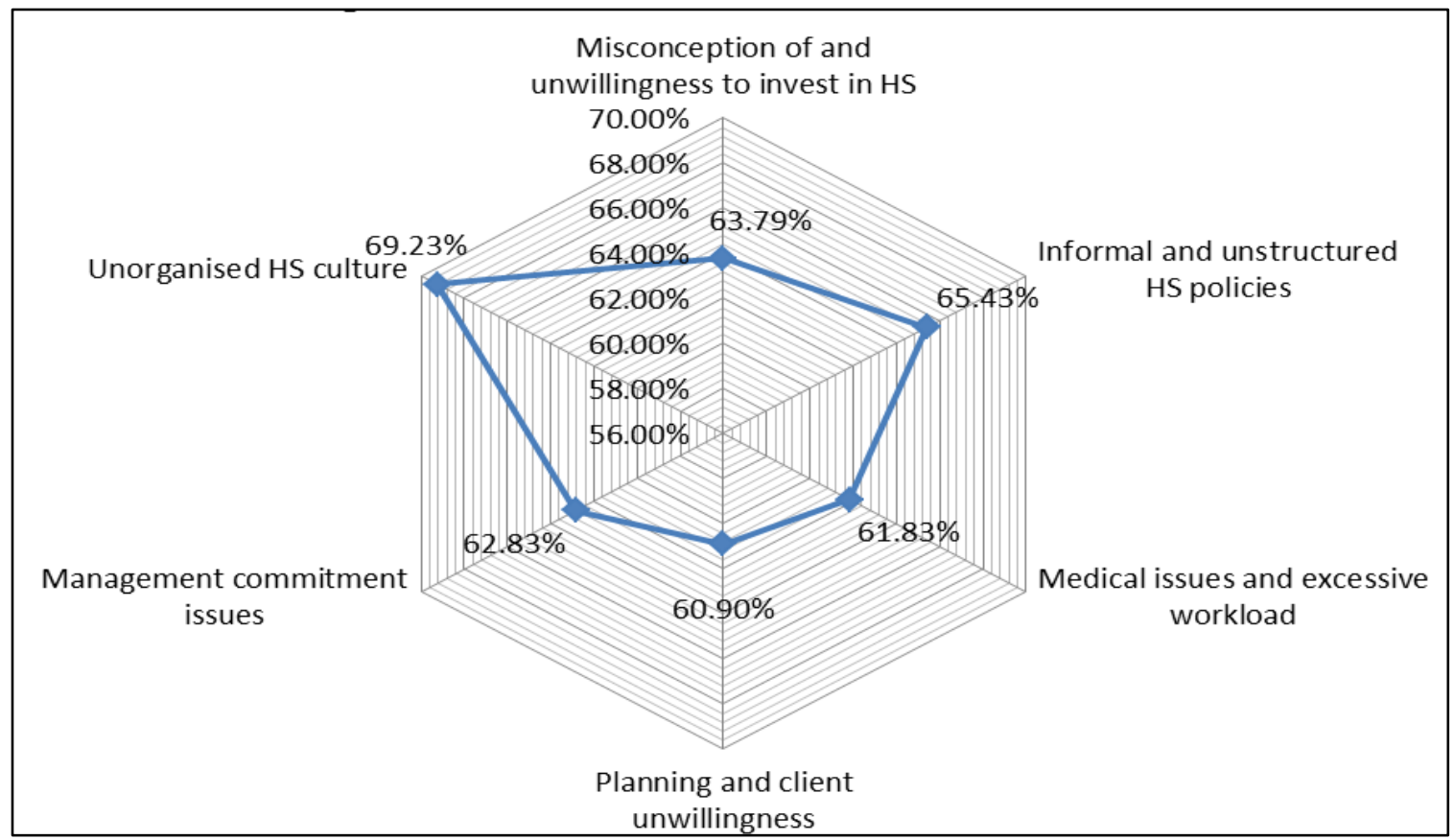

Figure 3: Relative mean of extracted factors

\section{CONCLUSION AND RECOMMENDATIONS}

This study assessed the factors promoting health and safety (HS) risks Normalisation in the construction industry of developing countries. The study gathered information from construction professionals and tradespeople engaged by construction SMEs in Abuja, Nigeria. With a fair representation of participants from both small and medium construction organisations and professionals and tradespeople alike, the study was able to determine the major clusters of factors causing the normalisation of health and safety risks in construction projects.

The study concludes that there is a low level of occupational health and safety policies application and performance in the construction industry. This poor health and safety performance is caused by HS risks normalisation promoted by factors such as misconception of and unwillingness to invest in HS, informal and unstructured HS policies, medical issues and excessive workload, planning and client unwillingness, management commitment issues, and unorganised HS culture.

Based on the findings, the study makes the following recommendations for improving health and safety performance of construction projects and the overall project delivery successes.

a) Awareness and safety implementation campaigns in the construction industry and particularly among construction SMEs which makes up the bulk of the construction 
firms in the industry. This will allay the fear and misconception they hold regarding the need to invest in safety;

b) Formalisation and use of structured health and safety policies and programmes. This involves having consistent and firm HS regulations and practices and ensuring the adequate estimation of safety risks. This will eliminate the lack of maintenance of tools and equipment, and by extension the safety and overall performance of the projects;

c) The taking of medical examination for new project recruits serious to avoid people with underlying health issues from constituting hazards to the others and themselves. This will eliminates accidents and loss of man-hour on construction sites. By ensuring that workers do not take more than they can handle, and the engagement of adequate manpower across every level of the organisation's hierarchy and making use of PPE a must prior to entering construction site environment;

d) Use of well-developed and detailed health and safety management plan. This will ensure that a safe tasks execution plan, reduced health and safety cost as a result of reduced accidents, and the responsibility for safety should be on management and not the casual and temporary workers;

e) Commitment from the management and leadership of the SMEs and making of health and safety culture an integral part of the functioning of the organisations. This will increase the health and safety conscientiousness of every stakeholder. It will increase workplace safety conditions and instil discipline and increase adherence to safety practices. A sound organisational health and safety culture will ensure the refocusing of management on adequate safety over productivity.

The uniqueness of the study lies in the incorporation of the perception of construction artisans and tradespeople as against the popular sampling of construction professionals' alone on health and safety-related studies. This study adds to the available body of knowledge on health and safety practices in the construction industry. The study will assist managers/owners of SMEs to make an informed decision regarding health and safety decisions of their organisations and construction sites.

Corporate clients and consultants will help in making HS an integral part of contractors' pre-qualification and selection criteria. Also, construction firms are presented with information that will guide their safety management strategies and safety improvement and performance. It will also serve as a focal point for government Institutionalisation and legislation of laws 
DOI: 10.14807/ijmp.v12i5.1417

governing labour engagement would be underpinned to fight against the continuous casualization and use of temporary workforce.

The limitation of this study is in it's sample size and geographical boundary. Thus, care should be taken in generalising the findings. However, a similar study should be carryout out in other states or parts of the country or region or developing countries, so that results could be compared. A quantitative relationship between the characteristics of construction SMEs and health and safety performance needs investigation. Also, requiring investigation is the impact of HS deviance normalisation on the organisation, project and employees performance.

\section{REFERENCES}

Abas, N. H., Jalani, A. F. A. J., \& Affandi, H. M. (2020). Construction Stakeholders' Perceptions of Occupational Safety and Health Risks in Malaysia. Journal of Sustainable Construction Engineering and Technology, 11(1), 300-311. DOI: https://doi.org/10.30880/ijscet.2020.11.01.029

Abdi, H., \& Williams, L. J. (2010). Principal component analysis. Wiley Interdisciplinary Reviews:Computational Statistics, 2(4), 433-459.

Aghimien, D., Aigbavboa, C., Thwala, G., \& Thwala, W. (2019). Critical Drivers for Health and Safety Management among SMEs in the Eswatini Construction Industry. 1st International Conference on Sustainable Infrastructural Development. IOP Conference Series: Materials Science and Engineering, (640), 1-9. doi:10.1088/1757899X/640/1/012005

Aghimien, D. O., Oke, A. E., Aigbavboa, C. O., \& Ontlametse, K. (2018). Factors Contributing to Disabling Injuries and Fatalities in the South African Construction Industry. Joint CIB W099 and TG59 International Safety, Health, and People in Construction Conference, held in Salvador, in Brazil in 1st -3rd of August, 337-345

Arewa, A. O., \& Farrell, P. (2012). A review of compliance with health and safety regulations and economic performance in small and medium construction enterprises In: Smith, S. D (Ed). Procs 28th Annual ARCOM Conference, 3-5 September 2012, Edinburgh, UK, Association of Researchers in Construction Management, 423-432

Arocena, P., \& Núñez, I. (2010). An empirical analysis of the effectiveness of occupational health and safety management systems in SMEs. International Small Business Journal, 28(4), 398-419.

Arunkumar, K., \& Gunasekaran, J. (2018). Causes and effects of accidents on construction site. International Journal of Engineering Science and Computing, 8(6), 18102-18110

Atkinson, R., 7 Flint, J. (2001). Accessing hidden and hard-to-reach populations: snowball research strategies. Social Research Update, Issue 33, published by Department of Sociology University of Surrey, Guildford, United Kingdom.

Bagaya, O., \& Song, J. (2016). Empirical study of factors influencing schedule delays of public construction projects in Burkina Faso. Journal of Management Engineering. 32(5), 05016014. https://doi.org/10.1061/(ASCE).ME.1943-5479.0000443. 
Barbeau, E., Roelofs, C., Youngstrom, R., Sorensen, G., Stoddard, A., \& Lamontagne, A. D. (2004). Assessment of occupational safety and health programs in small businesses.

American Journal of Industrial medicine, 45(4), 371-379. Doi:10.1002/ajim.10336

Belayutham, S., \& Ibrahim, C. K. I. Z (2019). Barriers and Strategies for Better Safety Practices: The Case of Construction SMEs in Malaysia. Construction Economics and Building, 19(1), Article ID 6331. https://doi. org/10.5130/AJCEB.v19i1.6331

Bell, J., \& Healey, N. (2006). The Causes of Major Hazard Incidents and How to Improve Risk Control and Health and Safety Management: A Review of the Existing Literature. Health and safety Laboratory, Harpur Hill, Buxton Derbyshire, SK17 9JN. Availavle at: https://www.hse.gov.uk/Research/hsl_pdf/2006/hsl06117.pdf

Berr (2008). Improving outcomes from health and safety. A report to Government by the Better Regulation Executive. Department for Business Enterprises and Regulatory Reform, London, August), 6-29.

Champoux, D., \& Brun J. (2003). Occupational health and safety management in small size enterprises: an overview of the situation and avenues for intervention and research. Safety Science, 41(4), 301-318.

Chiocha, C., Smallwood, J., \& Emuze, F. (2011). Health and safety in the Malawian construction industry. Journal of Acta Structilia, 18(1), 68-80

CIDB (2018). Construction Industry Review \& Prospect 2016/2017: Chapter 2 Construction Projects, Contractors and Personnel. Available at: http://www.cidb.gov.my/images/content/pdf/bisnes/ const-review-2016-2017/CIDB---Construction-Industries-Review---Chapter-2-Jan-15-2018.pdf (Accessed 10 March 2019).

Cresswell, J. W., \& Plano, C. V. L. (2011). Designing and Conducting mixed method research (2nd ed.).. Thousand Oaks, CA: Sage

EU-Osha, (2014). The Business Case for Safety and Health at Work: Cost-benefit Analyses of Interventions in Small and Medium-sized Enterprises. European Agency for Safety and Health at Work, Luxembourg.

Eashw (2003). FACTS 37. Improving occupational safety and health in SMEs: example of effective assistance. European Agency for Safety and Health at Work. Summary of an Agency report, Gran-Bibao), 1-2.

European Commission. (2015). User guide to the SME definition. Luxembourg: Publications Office of the European Union

Eze, E. C., Seghosime, R., Eyong, O. P., \& Loya, O. S. (2017). Assessment of materials waste in the construction industry: A view of Construction Operatives, Tradesmen and Artisans in Nigeria. The International Journal of Engineering and Science, 6(4), 32-47. DOI: $10.9790 / 1813-0604013247$

Eze,C. E., Awodele, I. A., Adegboyega, A. A., Onyeagam, O. P., \& Guto, J. A. (2020). Assessment of the Triggers of Inefficient Materials Management Practices by Construction SMEs in Nigeria. International Journal of Real Estate Studies, 14(1), 38-56

Field A. (2000). Discovering Statistics using SPSS for Windows. London: Sage publications.

Floyde, A., Lawson, G., Shalloe, S., Eastgate, R., \& D’cruz, M. (2013). The design and implementation of knowledge management systems and e-learning for improved 
occupational health and safety in small to medium sized enterprises. Safety Science(60), 6976.

Gao, R., Chan, A. P. C., Utama, W. P., \& Zahoor, H. (2017). Workers’ Perceptions of Safety Climate in International Construction Projects: Effects of Nationality, Religious Belief, and Employment Mode. Journal of Construction Engineering and Management, 143(4), 04016117, https://doi.org/10.1061/(ASCE).CO.1943-7862.0001226.

Ghasem, A., \& Zahediasl, S. (2012). Normality test for statistical analysis: A guide for nonstatisticians. International Journal Endocrinol Metab., 10(2), 486-489.

Gulani, M. G., \& Usman, A. (2012). Financing small and medium scale enterprises (SMEs).: A challenge for entrepreneurial development in Gombe State. Asian Journal of Business and Management Sciences, 2(9), 17-23.

Gunduz, M., \& Laitinen, H. (2018). Construction safety risk assessment with introduced control levels. Journal of Civil Engineering and Management, 24(1), 11-18. https://doi.org/10.3846/jcem.2018.284

Hair, J. F., Black, W. C., Babin, B. J., \& Anderson, R. E. (2010). Multivariate data analysis. Upper Saddle River, NJ: Pearson.

Hasle, P., Bager, B., \& Granerud, L. (2010). Small enterprises - Accountants as occupational health and safety intermediaries. Safety Science, 48(3), 404-409.

Hasle, P., Kvorning, L. V., Rasmussen, C. D. N., Smith, L. H., \& Flyvholm, M. A. (2012). A model for design of tailored working environment intervention programmes for small enterprises. Safety Health Work(3), 181-191. https://doi.org/10.5491/SHAW.2012.3.3.181

Hasle, P., \& Limborg, H. J. (2006). A review of the literature on preventive occupational health and safety activities in small enterprises. Industrial Health, 44(1), 6-12.

Heckathorn, D. D. (2011). Comments: snowballing versus respondent-driven sampling. Sociological Methodology, 41(1), 355-366.

IBM (2011).. IBM SPSS Statistics for Windows, Version 20.0. Armonk, NY: IBM Corp. Jaroenroy, T., \& Chompunth, C. (2019). An Alternative Integrated Occupational Health, Safety and Environmental Management System for Small And Medium-Sized Enterprises (SMEs). In Thailand. International Journal of Geomate, 17(62), 84 -91. Doi: Https://Doi.Org/10.21660/2019.62.8168

Jennings, P. (2016). Have you become victim to the normalization of risk? https://blog.hsb.com/2016/08/04/normalization-of-deviance/

Jørgensen, K., Duijm, N. J., \& Troen, H. (2011). Demonstration of risk profiling for promoting safety in SMEs. International Journal of Workplace Health Management, 4(2), 179-193.

Kadiri, Z. O., Nden, T., Avre, G. K., Oladipo T. O., Edom, A., Samuel P. O., \& Ananso, G. N. (2014). Causes and Effects of Accidents on Construction Sites (A Case Study of Some Selected Construction Firms in Abuja F.C.T Nigeria. Journal of Mechanical and Civil Engineering (IOSR-JMCE)., 11(4), 66-72

Kheni, N., Gibb, A., \& Dainty, A. (2010). Health and Safety Management within Small- and Medium-Sized Enterprises (SMEs). in Developing Countries: Study of Contextual Influences. Journal of Construction Engineering and Management, 136(10), 1104-1115. 
Kolo , D. N. (2015). Safety Issues Involving Workers on Building Construction Sites in Nigeria: An Abuja Study. MSc Thesis, Eastern Mediterranean University, Gazimağusa, North Cyprus

Laryea, S., \& Mensah, S. (2010). The evolution of indigenous contractors in Ghana. In: Laryea, S., Leiringer, R., \& Hughes, W. (Eds). Procs West Africa Built Environment Research (WABER). Conference, 27-28 July, Accra, Ghana, 579-588.

Legg, S. J., Olsen, K. B., Laird, I. S., \& Hasle, P. (2015). Managing safety in small and medium enterprises. Safety Science, (71,Part C), 189-196.

Lin, J., \& Mills, A. (2001). Measuring the occupational health and safety performance of construction companies in Australia. Facilities, 19(3/4), 131-139.

Lingard, H. (2013). Occupational health and safety in the construction industry.

Construction Management and Economics, 31(6), 505-514

Lingard, H., \& Blismas, N. (2013). Client OHS leadership: An evaluation of client leadership in occupational health and safety in the Australian construction industry. RMIT University, Melbourne, 2013.

Loosemore, M., \& Andonakis, N. (2007). Barriers to implementing OHS reforms - The experiences of small subcontractors in the Australian Construction Industry. International Journal of Project Management(25), 579-588.

Lu, L. (2018). Promoting SME finance in the context of the fintech revolution: A case study of the UK's practice and regulation. Banking and Finance Law Review, 33(3), 317-343.

Manu, P., Mahamadu, A-M., Phung, V. M., Nguyen, T. T., Ath, C., Heng, A. Y. T., \& Kit, S. C. (2018). Health and safety management practices of contractors in South East Asia: A multi country study of Cambodia, Vietnam and Malaysia. Safety Science, (107), 188-201.

Masi, D., Cagno, E., \& Micheli, G. J. L. (2014). Developing, Implementing and Evaluating OSH Interventions in SMEs: A Pilot, Exploratory Study. International Journal of Occupational Safety and Ergonomics, 20(3), 385-405,

DOI:10.1080/10803548.2014.11077059

Mohamed, S., Ali, T. H., \& Tam, W. Y. V. (2009). National culture and safe work behaviour of construction workers in Pakistan. Safety Science., 47(1), 29-35.

Naderifar, M., Goli, H., \& Ghaljaie, F. (2017). Snowball Sampling: A Purposeful Method of Sampling in Qualitative Research. Strides Dev Med Education, 14(3), 1-6. Doi: 10.5812/sdme.67670

National Bureau Of Statistics. (2019). Micro, small and medium enterprises (MSEM). national survey 2017 report. Abuja: NBS.

Okoye, P. U. (2018). Occupational health and safety risk levels of building construction trades in Nigeria. Construction Economics and Building, 18(2), 92-109. http:// dx.doi.org/10.5130/AJCEB. v18i2.5882

Okoye, P. U., \& Okolie, K. C. (2014). Exploratory study of the cost of health and safety performance of building contractors in South-East Nigeria. British Journal of Environmental Sciences, 2(1), 21-33.

Orji, E., Enebe, E. C., \& Onoh, F. E. (2016). Accidents in Building Construction Sites in Nigeria; a Case of Enugu State. International Journal of Innovative Research, 5(4), 244248 
Othman, I., Shafiq, N., \& Nuruddin, M. F. (2017). Quality planning in Construction Project. IOP Conf. Series: Materials Science and Engineering 291), 1-5

Ozmec, M. N., Karlsen, I. L., Kines, P., Andersen, L. P. S., \& Nielsen, K. J. (2014).

Negotiating safety practice in small construction companies, Safety Science(71,Part C), 275281.

Pallant, J. (2005). SPSS Survival Manual: A Step By Step Guide to Data Analysis Using SPSS for Windows (Version 12)., (2nd ed.).. Allen and Unwin, Crows Nest NSW 2065.

Pallant, J. (2007). SPSS survival manual: A step-by-step guide to data analysis using SPSS (version 15)., (3rd ed.).. Milton Keynes: Open University Press.

Randy, B (2017). Normalization of deviance and risk management. http://roughnotes.com/normalization-deviance-risk-management/

Rizwan, U. F. (2012). An Exploratory Study Probing Into the Factors Causing Safety NonPerformance in the Pakistani Construction Industry,” in 45th IEP Convention 2012, 1-12.

Shabangu, N. I. (2017). Health and Safety Culture on Small Residential Construction

Sites: The Case of Waterfall Country Estate, Midrand. A Research Report proposal submitted to the Faculty of Engineering and the Built Environment, in partial fulfilment of the requirements for the degree of MSc (Building). Project Management in Construction, University of the Witwatersrand, Johannesburg, South Africa

Shafii, H. B., Bin-Shahna, E. A., Meryam, S., \& Md Yassin, A. (2019). Study On Promote Occupational Safety And Health Practices In Construction Projects. Journal Of Technology Management And Business, 6(3), 029-039

SMEDAN/NBS MSME Survey. (2013). SMEDAN and National Bureau of Statistics collaborative survey: Selected findings. Abuja: NBS. Retrieved from https://www.smedan.gov.ng/images/PDF/2013-MSME-Survey-Summary-Report.pdf.

Spector, P. E. (1992). Summated rating scale construction: An introduction. Newbury Park, CA: Sage Publications.

Stern, L. (2010). A visual approach to SPSS for Windows: a guide to SPSS 17.0. 2nd ed. Boston: Allyn and Bacon

Stiles, S., Golightly, D., \& Wilson, J. R., (2012). Behavioural safety amongst construction industry supply chain contractors, in: M. Anderson (ed.)., Contemporary Ergonomics and Human Factors, Taylor \& Francis, 303-310.

Sunindijo, R. Y. (2015). Improving safety among small organisations in the construction industry: key barriers and improvement strategies. The 5th International Conference of Euro Asia Civil Engineering Forum (EACEF-5).. Procedia Engineering(125), 109 - 116

Surienty, L. (2012).. Management practices and OSH implementation in SMEs in Malaysia. School of Management, USM Minden, Pulau Pinang.

Szóstak, M. (2019). Analysis of occupational accidents in the construction industry with regards to selected time parameters. Open Engineering(9), 312-320.

Tabachnick, B. G., \& Fidell, L. S. (2007). Using multivariate statistics (5th ed.).. Boston, MA: Pearson.

Tan, W. C. K. (2011). Practical research methods. Pearson Custom, Singapore.

Thwala, W. D., \& Mvubu, M. R. (2009). Problems Facing Small and Medium Size Contractors in Swaziland. Journal Service Science and Management(2), 353-361 
Unnikrishnan, S., Iqbal, R., Singh, A., \& Nimkar, I. M. (2015). Safety Management Practices in Small and Medium Enterprises in India. Journal Safety and Health at Work, 6(1), 46 55

Usman, N. D., Inuwa, I. I., Kolawole, R. O., Kwari, J. M., \& Didel, J. M. (2014). Evaluating the impact of housing delivery system on project performance within the building industry in Nigeria. Journal of Environmental Sciences and Resource Management, 6(1), 145-154.

Wadick, P. (2010). Safety culture among subcontractors in the domestic housing construction industry. Structural Survey, 28(2), 108-120.

Whysall, Z., Haslam, C., \& Haslam, R. (2006). Implementing health and safety interventions in the workplace: an exploratory study. International Journal of Indsutrial Ergonomics, 36(9), 809-818

Williams, O. S., Hamid, R. A., \& Misnan, M. S. (2018). Accident Causal Factors On the Building Construction Sites: A Review. International Journal of Built Environment and Sustainability (IJBES), 5(1), 78-92

Ye, G., Jin, Z., Xia, B., \& Skitmore, M. (2015). Analyzing causes for reworks in construction projects in China. Journal of Management Engineering, 31(6), 04014097. https://doi.org/10.1061/(ASCE).ME.1943-5479.0000347.

Ying, J., Wong, Y., Gray, J., \& Sadiqi, Z. (2015). Barriers to Good Occupational Health \& Safety (OHS). Practices by Small Construction Firms), 1-18. Available at https://www.researchgate.net/publication/281495184

Zahoor, H., Chan, A. P. C., Utama, W. P., \& Gao, R. (2015). A research framework for investigating the relationship between safety climate and safety performance in the construction of multi-storey buildings in Pakistan. Procedia Engineering(118), 581 - 589

Zhao, J., Joas, R., Abel, J., Marques, T., \& Suikkanen, J. (2013). Process safety challenges for SMEs in China. Journal of Loss Prevention in the Process Industries, 26(5), 880-886.

Zhao, N. (2008). The minimum sample size in factor analysis. Retrieved from https://www.encorewiki.org/plugins/servlet/mobile\#content/view/25657. 